\title{
Eğitim Örgütlerinde Siber Zorbalık Tutumları İle Örgütsel Dışlanma Arasındaki İlişki ${ }^{1}$
}

DOI: $10.26466 /$ opus.894335

$*$

\section{TuğrulÖz ${ }^{*}-\underline{\text { Yar Ali Mete }}{ }^{* *}$}

*Y1. Öğr., Trakya Üni. ,Sosyal Bilimler Enstitüsü, Balkan Yerleşkesi, Edirne / Türkiye

E-Posta: tugrul oz@hotmail.com ORCID: 0000-0003-3858-7348

**Dr. Öğr. Üyesi, Trakya Üniversitesi, EğitimFakültesi, Kosova Yerleşkesi, Edirne / Türkiye

E-Posta: yaralimete@trakya.edu.tr

ORCID: $\underline{0000-0001-5469-1829}$

\section{Öz}

Bu araştırmanın amacl; Edirne ilindeki ĕ̆itim örgütlerinde görev yapan öğretmenlerin siber zorbalık tutumları ile örgütsel dışlanma tutumları arasındaki ilişkiyi ortaya koymaktır. Araştırmanın çalışma grubunu 2017-2018 Eğitim-Öğretim yılında Edirne'de resmi/özel ilk ve orta dereceli okullarda görevli 328 öğretmen oluşturmuştur. Veri toplama aracı olarak öğretmenlere üç boyuttan oluşan Siber Zorbalık Ölçeği ile dört boyuttan oluşan Örgütsel Dışlanma Ölçeği, araştırmacılardan izin alınarak öğretmenlere gönüllülük esasına riayet edilerek uygulanmıştır. Siber zorbalık davranışları ile örgütsel dışlanma arasındaki ilişkiyi betimleyerek dĭger bağımsız değişkenlerin etkilerini de ortaya koymaya yönelik ilişkisel tarama modeli ile desenlenen araştırmada, öğretmenlerin yanıtladı̆̆ı siber zorbalık ölçeğinin ortalamaları ile örgütsel dışlanma ölçeğinin ortalamalarının çok düşük düzeyde negatif yönlü anlamlı bir ilişki olduğu tespit edilmiştir. Yaş, cinsiyet, sosyal ağları kullanım amaçları, sosyal ağlarda geçirilen süre, çalışma ortamındaki iletişim yeterliliği düzeyi, meslekte geçirilen çalışma süresi gibi değişkenlerin açısından öğretmenlerin siber zorbalık tutumları arasında anlamlı bir farklılık göstermediği görülmüştür. Son olarak öğretmenlerin örgütsel dışlanma tutumlarının ise sadece çalışma ortamındaki iletişim düzeyi yeterliliği değişkenine göre anlamlı bir farklllık gösterdiği görülmüştür.

AnahtarKelimeler: $\quad$ Siber Zorbalık, Örgütsel Dışlanma, Ĕ̆itim Örgütleri

\footnotetext{
${ }^{1}$ Bu makale Trakya Üniversitesi, Sosyal Bilimler Enstitüsü "Eğitim Örgütlerinde Siber Zorbalık İle Örgütsel Dışlanma Arasındaki İlişki ( Edirne İli Örneği)" adlı Yüksek Lisans tezinden üretilmiştir.
} 


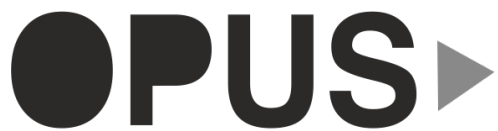

Uluslararası Toplum Araştırmaları Dergisi International Journal of Society Researches
E-ISSN : 2528-9535

YIl Year: 11

Cilt Volume: 18

Sayı Issue :Yönetim ve Organizasyon Özel Sayısı

TemmuzJuly 2021

Makalenin Gelis Tarihi Received Date: 15/03/2021

Makalenin Kabul Tarihi Accepted Date: 08/05/2021

\title{
The Relationship between Cyberbullying and Organizational Exclusion in Educational Organizations
}

\begin{abstract}
The purpose of this research; The aim of this study is to reveal the relationship between cyberbullying attitudes and organizational exclusion attitudes of teachers working in educational organizations in Edirne Province. The study group of the study consisted of 328 teachers working in public / private primary and secondary schools in Edirne in the 2017-2018 academic year. As a data collection tool, three dimensions Cyber Bullying Scale and Organizational Exclusion Scale consisting of 4 dimensions wereapplied to the teachers on a voluntary basis with the permission of the researchers. In this study conducted by using a relational screening model to describe the relationship between cyberbullying behaviors and organizational exclusion by revealing the effects of other independent variables, in the study, themean of the cyberbullying scale answered by the teachers and the mean of organizational exclusion scale were found to be very low. It was observed that variables such as age, gender, aims of using socialnetworks, time spent in social networks, level of communication competence in working environment, and duration of work spent in the profession did not show a significant difference between teachers' cyberbullying attitudes. It was observed that the teachers' organizational exclusion attitudes differed only according to the communication level competence variable in the working environment.
\end{abstract}

KeyWords: Cyberbullying, Organizational Exclusion, Educational Organizations. 


\section{Giriş}

Günümüzde hızla gelişen ve gün geçtikçe kullanımı yoğun olarak artan bilişim teknolojileri gündelik hayatımızın vazgeçilmez birer parçası haline gelmiştir (Erdur-Baker ve Kavşut, 2007). Özellikle bilişim teknolojileri gibi gelişmiş iletişim araçları olumlu anlamda ve bilinçli olarak kullanıldığında günlük hayatımızdaki sorunlarımıza rehberlik ederek çözüm ve öneri yolları sağlarken; amaçlı, kasıtlı, birey ya da gruplara zarar verici anlamda kullanıldığında ise problemler, yaşam boyunca kalıcı ve kronik yaşantılar oluşturabilecek durumlara neden olabilmektedir (Peker ve İskender, 2015).

Türkiye İstatistik Kurumu'nun 2018 yılında ortaya koyduğu göstergelere göre ülkemizde internet ve bilgisayar kullanımı 2018 Ağustos ayı itibariyle 16-74 yaş aralığındaki bireylerde sırasıyla \%59,6-\%72,9 aral1ğında olarak tespit edilmiş olup ülkemizde hanelerin \%79,4'ünde bilgi ve iletişim araçları bulunmaktadır (TÜİK, 2019).Yaşamın her alanında cep telefonu ve bilgisayar gibi bilgi iletişim araçlarının kullanımının artması ve bu araçların bilinçsiz bir şekilde kullanımıyla birlikte bireylerin sanal dünyada şiddet ve unsurlarını içeren alanlarla etkileşimi, birbirlerine incitici davranışlarda bulunabilmesi, ruhsal durumlarını etkileyebilecek (taciz, tehdit, hakaret etme vb.) maddi ve manevi mağduriyet yaşaması gibi travmaların yaşanması ihtimalini arttırmaktadır (Dalmaç Polat ve Bayraktar, 2016).Bilgi ve iletişim teknolojileri araçlarıyla yaygın, belirli mekan ve zamanla sınırlı olmayarak zarar verici eylemlemlerin gerçekleştirilebileceği düşünüldüğünde bireylerin duygusal, sosyal ve kişilik düzeylerini etkileyerek yabancılaşma yaşamaları, benlik saygılarını yitirebilmeleri, sosyal etkileşimden kaçınmaları, öfke ve üzüntü yaşayabilmeleri gibi durumlar oluşturabilmektedir (Şahin, Sarı, Özer, ve Er, 2010).

Çalışma ortamında görülen siber zorbalık davranışlarının çalışanların stres düzeyleri arasında pozitif yönlü ilişki olduğu vurgulanmakla birlikte, siber zorbalık çok ciddi seviyede olumsuz duygusal etkilere, düşük özgüvene, çalışma ortamındaki verimliliğin düşmesine, çalışanların destek sistemleri bulmada özgüven yetersizliği yaşamalarına, işyerindeki problemleri ile mücadele etmekte başarısız olmalarına ve çalışma ortamında kendini zihinsel olarak incinmiş hissetmelerine neden olmaktadır (Kanbur ve Kanbur, 2018). Çalışma ortamında yaşanan siber zorbalığın 
bireyler açısından ciddi bir işyeri sorunu olduğu, iş doyumu, çalışanların refahı ve örgütsel performans için olumsuz etkileri olduğu ortaya konulmuştur (Coyne, Farley, Axtell, Sprigg, Best, ve Kwok, 2017).

İstenmeyen durumların oluşabilmesine zemin hazırlayabilecek davranışların görüldüğü bir çalışma ortamında, örgüt performansının değerlendirilmesi ve sağlıklı bir şekilde işlevlerini yerine getirmesi önem arz etmektedir. Performans, bir örgütün kaynaklarını etkin ve verimli kullanarak amaçlarına ulaşabilme yeteneği olarak anlaşılmakta, örgüt performansı ise belirli bir süreç sonucundaki göstergelere göre örgütlerin amacının ya da işlevinin yerine getirilme düzeyinin ifadesi olarak görülmektedir (Doğan ve Altunoğlu, 2014).

Çolakoğlu ve Sökmez (2018), öğretmenlerde siber zorbalığa yönelik 662'si kadın, 1500'ü erkek olmak üzere toplam 2162 öğretmenle yapılan bilimsel çalışmanın sonuçlarına göre öğretmenlerin neredeyse yarısının "siber zorbalık mağduru" olduğu bulgulanmıştır. Araştırma sonuçlarında erkek öğretmenlerin kadınlara göre daha fazla siber zorbalıkla karş1laştığ1 fiziksel güç eşitsizliği nedeniyle kadınların yüz yüze zorbalıkla karşılaştığ1 görülmüştür. Araştırma sonuçlarından öğretmenlerin yaklaşık \%19'unun dışlanmaya maruz kaldığı bulgulanmıştır (Akt:Çakmakçı, 2018).

Öğretmenler, stres ve türevlerini yoğun olarak yaşayan önemli işlerden birine sahiptir. Öğretmenlerin başarılarının büyük bir kısmı mesleki motivasyon, olumlu örgüt iklimi ve kültürünün olması ve iyi benimsenmiş örgütsel amaçların sonucunun göstergesidir. Öğretmenlerin günlük stres kaynaklarına ilaveten, çalışma ortamında meslektaşları tarafından dışlanma hissi yaşamaları, mesleki başarılarını ve bununla birlikte örgütsel amaçlarını gerçekleştirmeleri önündeki güçlükleri daha da arttıracaktır. Bu nedenle, yöneticiler öğretmenleri koruyucu, destekleyici ve kapsamlı okul kültürünün ve anlayışının geliştirilmesine odaklanmaları gerekmektedir. Okul yöneticilerinin, olumlu ve örgütsel amaçları yerine getirme anlayışını geliştiren örgüt iklimi oluşturması dışlanmanın kötü etkileri ve öğretmenlerin memnuniyetsizlikleri gibi sorunları asgari düzeye indirmesine yardımcı olabileceği gibi eğitim ve öğretim kalitesi ve düzeyinin arttırılmasına katkı sağlayacaktır (Dönmez, 2018).

Öğretmenler dişlanmaya neden olan etmenlerin bireysel, siyasi, örgütsel ve toplumsal nedenler olduğunu siralamaktadır. Bireysel olarak 
dışlanmanın psikolojik rahatsızlıklara, performansın düşmesine, motivasyon kaybı yaşayarak meslekten soğumasina neden olduğu vurgulanmaktadır. Örgüt açısından ise dışlanmanın eğitim ve öğretim süreçlerinin aksamasına, örgüt ikliminin zarar görmesine, örgüt çalışanlarının aidiyet duygularının azalmasına ve örgüt içinde çatışmalara yol açtığ1 ortaya konulmuştur (Erdemli ve Kurum, 2019).

Hem örgütsel açıdan hem de bireysel açından bakıldığında çalışma ortamında görülebilecek dışlanma, bireylerin kendilerini mutsuz hissetme, uygunsuz çalışma davranışları gösterme, işi bırakma, çalışma ortamındaki performansın düşmesi, sapkın davranışlar göstermekle birlikte dışlanmanın psikolojik bozukluklara, kendini tükenmiş hissetme, çalı̧̧ma ortamında gerginlik, elverişsiz iş durumuna, iş performansına katkı sağlayan unsurların azalmasına neden olabileceği hem çalışanlara hem de örgütlere önemli derecede zarar veren bir etkisinin olduğu belirtilmektedir (Çelik ve Koşar, 2015).

\section{Kavramsal Çerçeve}

\section{Siber Zorbalık}

Siber alan, teknolojiye bağlı olarak gelişmekte olan internetin bir sonucu olarak ortaya çıkmıştır. Bu alan internet üzerinde siber ortam olarak adlandırılır. Siber ortamı dile getiren ilk kişi Amerikalı yazar William Gibson'dur. Gibson, siber ortamı "Neuromancer" (1984) isimli romaninda: "Siber alan, matematiksel ifadelerin kişiler açısından, milyarlarca komut sistemi içerisinde yer alan yasal operatörler tarafından sınanarak, her an yaşanan içgüdüsel ve tepkisel bir halüsülasyon olduğunu ve bilgisayarların algoritmalarından elde edilen verilerin grafiksel olarak gösterildiği karmaşık, işlemler kümesi olarak adlandırmıştır. Bu alanlar bir bilgisayar programı aracılığıyla internet bağlantısı olan her türlü elektronik cihazda bire bir etkileşimli olarak kullanıldığı ortamlardır (Gibson,1984;Akt:Güzel, 2006).

1993 yılında İsviçre'nin CERN merkezinde Tim Lee Berners tarafından geliştirilen World WideWeb'in kuruluşundan itibaren internet ortamı inşa edilmiş ve baş döndürücü hızla gelişen sanal ortam, zamanla yeni bir kültürü içerisinde oluşturmuş ve internet kültürü de kendi içeri- 
sinde bir dönüşüm yaşamıştır. 2000'li yıllarda ise web 2.0 ve sosyal medya kavramlarıyla geliştirilerek günümüzün dijital kültürünü oluşturan en önemli unsurlardan biri olarak ortaya çıkmıştır (Karakulakoğlu, 2012).

Siber zorbalık, bilişim teknolojileri yoluyla yapılan sosyal, psikolojik ve toplumsal ilişkilere tehdit oluşturabilen ve süreklilik arz eden, teknik ve ilişkisel olarak zarar verici eylemlerden oluşan bir saldırganlık çeşididir (Korkmaz, 2016).Bilişim teknolojilerinin yaygınlaşması ve her yönüyle hayatımızın içinde var olmasıyla birlikte istenmeyen zararlı davranışlarda sanal ortama taşınarak daha kolay yapılabilir bir hal almış, bu davranışların yaygınlaştığı gözlemlenmiştir (Peker, 2015).

Siber zorbalıkta sergilenen davranışlar geleneksel zorbalıktaki davranış ve eylemlerle benzerlik göstermektedir. Mağdur olana kurban, kurbana zarar verene ise siber zorba denilmektedir. Sıklıkla amaçlı ve kasıtlı bir şekilde karşı birey ya da gruba zarar vermek amacıyla tekrarlayan eylemler olarak adlandırılmaktadır (Tamer ve Vatanartıran, 2015). Geleneksel zorbalık günlük hayatta karşılaşılan ve bilinen bir taciz biçimiyken siber zorbalık ise sanal ortamda yer ve zamandan bağımsız gerçekleştirilebilme olanağına sahiptir (Peker, Eroğlu, ve Ada, 2012). Siber zorbalığın görülme sıklığı ve yaygınlığı birçok araştırmacı tarafından ele alınmıştır. Siber zorbalığın hangi biçimde ve ortamlarda gerçekleştiğine yönelik yapılan çalışmalarda en çok gençler arasında ve çevrimiçi ortamlarda karşılaşıldığı görülmüştür. 2007 yılında A.B.D.'de yürütülen bir çalışmada siber zorbalık davranışı ve eylemlerinin en çok mesajlaşma, e-posta ve sohbet odaları aracılığıyla gerçekleştiği ortaya koyulmuştur. Ancak 2009 yılında bu kapsam genişletilerek günümüzde de sıklıkla kullandığımız bilgisayarlar, cep telefonları vb. gibi cihazları da içinde barındıracak şekilde genişletilmiştir (Sayımer ve Akca, 2017).

Dünyanın pek çok yerinden siber zorbalıkla ilgili olumsuz durum ve olaylar basına da yansımaktadır. Örneğin Avustralya'nın Melbourne şehrinde yaşayan bir Türk kızının, sosyal paylaşım sitelerindeki hesaplarını ele geçiren sanal zorbaların saldırı, baskı ve tehditlerine dayanamayıp hayatına son verdiği görülmüştür (Milliyet, 2012). Türkiye'deki araştırmalarda ise siber zorbalığın ilköğretim çağlarından başlayarak ciddi bir sorun haline gelmeye başladığ 1 görülmektedir. Serin (2012) tarafından yapılan bir araştırmada öğrencilerin \% \%'unun siber 
zorbalık yaptığı, \%12'sinin siber zorbalığa maruz kaldığı, \%5'inin ise siber zorba/mağdur olduğu rapor edilmiştir.Diğer bir ülke olan Kanada'da 177 öğrenciye uygulanan bir çalışmada, öğrencilerin \%54'ünün geleneksel zorbalık mağduru olduğunu katılımcı öğrenci sayısının çeyreğinden fazlasının siber zorbalık yaptığı bulgulanmıştır. Bu çalışma yaklaşık üç öğrenciden birinin diğer öğrencilere fiziksel yöntemlerle zorbalık yaptığını ve $\% 15^{\prime}$ e yaklaşık bir oranın ise bilgi iletişim araçlarını kullanarak zorbalık eylemlerine devam ettiğini göstermiştir (Erdur-Baker ve Kavşut, 2007). Siber zorbalık hakkında yapılan araştırmalarda, teknolojinin gelişmesi, bilgisayarların ve mobil cihazların gün geçtikçe yaygınlı̆̆ının ve kullanımının artması, sanal ortamda görülen siber zorbalık davranışlarını doğru orantılı bir şekilde arttırdığını ortaya koymaktadır (Akca, Sayımer, Salı, ve Başak, 2014). Siber zorbalık birçok şekilde yapılabildiği gibi bu davranışlarda bulunan bireyler, amaçlarını gerçekleştirmek için birçok iletişim araçlarından ve tekniklerden yararlanmaktadır. Siber zorbalık amacıyla kullanılan araçlar çeşitli kategorilere göre Yazılı Mesaj Zorbalığı,Fotoğraf / Video Klibi Zorbalığı, Telefon Zorbalığı, E- posta Zorbalığı, Sohbet Odası Zorbalığı, Sosyal Paylaşım Siteleri Aracilığıyla Zorbalık, Anlık Mesajlaşma Aracılığıyla Zorbalık, Web Siteleri Aracılığıyla Zorbalık olarak sıralanmaktadır (Baştak ve Altınova, 2015).Siber zorbalıkla ilgili yapılan araştırmalar incelendiğinde bu davranışların tek bir nedene bağlı olmadığı, davranışı sergilemeye neden olan etkilerin bireysel ve ailesel nedenler, kitle iletişim araçları, arkadaş çevresi ve okul ortamından kaynaklandığı, bireyleri zorbalıkta bulunma eğilimine soktuğu görülmektedir (Ümmetler İlhan, 2016). Siber zorbalık hiç kuşkusuz günlük yaşamda ve özellikle genç nesillerimizin yetiştiği okul ve çevresi üzerinde olumsuz etki uyandıran ve toplumsal travmalara yol açan faktörler arasında bulunmaktadır. Özellikle bireylerin zaman ve mekân kısıtından bağımsız olarak sanal ortamın yoğun olarak kullanıldığı ve mobil teknolojiler aracılığıyla anlık etkileşim yaşandığı göz önünde bulundurulduğunda siber zorbalıkla karşılaşılması, bireylerin bir şekilde etkilenmesine zemin hazırlamaktadır.Ülkemizdekiçalışmalar incelendiğinde siber zorbalığın olumsuz sonuçlarıyla ilgili önemli bulgulara ulaşılmıştır (Batmaz ve Ayas, 2013). 
Erdur-Baker ve Topçu (2008), ülkemizde ve dünyada siber zorbalığın etkileri ile ilgili yapılan çalışmalar basında yer alan haberlere ve araştırma sonuçlarına göre siber zorbalığa maruz kalma ve siber zorbalıkta bulunma oranlarının günden güne arttığını göstermektedir. Özellikle öncelikle toplumumuz olmak üzere fiziksel, psikolojik, ahlaki ve duygusal gelişimini aynı zamanda çocukların ve gençlerin akademik başarılarını da tehdit eden bir boyuta ulaştığı görülmektedir. Tüm bunlar açısından bakıldığında bu durumun daha ürkütücü boyutlara ulaşmaması adına siber zorbalıkla ilgili önleyici ve koruyucu programların yapılması gerekmektedir (Akt:Peker ve İskender, 2015). Kestel ve Akbıyık (2016)'ya göre yapılan araştırmaların diğer sonuçlarına göre öğrencilerin akademik başarıları üzerinde derslerine yoğunlaşamama, ders çalışma sırasında sorunlar yaşama ve odaklanma sorunu gibi problemleri, mağduriyetleri boyunca yaşamaktadırlar. Ayrıca anne-baba iletişimi ve ilgi düzeyinin eksikliği var olan sorunu paylaşamama gibi bireyin kişilik özellikleri de bu durumu daha çıkmaz hale getireceği açıktır. Yapılmış olan tüm bu çalışmalar siber zorbalık davranışı ve bu davranışı tetikleyen öğelerin bireylerde önemli psikolojik rahatsızlıklara yol açtığını ve buna bağlı olarak sosyal hayatta önemli sorunlar doğurduğunu, toplumsal huzuru dolaylı olarak rahatsız ettiğini göstermektedir. En önemli konulardan birisi de siber zorbalığın tanınması baş etme ve en aza indirme yöntemlerinin bilinmemesidir. Bu bakımdan, siber zorbalı̆̆ önleme ve başetme faaliyetleri üzerinde önemle durulması gereken bir konudur (Akt:Uluçay ve Melek, 2017).

\section{Örgütsel Dişlanma}

Dışlanma; insanların bulundukları ortamdan yok sayılması ya da görmezden gelinmesi davranışlarını içeren eylemlerin tümü olarak tanımlanmaktadır. Ayrıca bireylerde psikolojik sorunlara yol açabilen kişilerarası stres kaynağıdır. Dışlama, bir başka deyişle bir kişi veya gruba karşı, dikkat ve doğrudan kaynaklanan iletişim eksikliğidir (Çelik ve Koşar, 2015).

Örgütsel dışlanma ise birden fazla kişi ve iş gören tarafından dikkate alınmama ya da grup dışında ayrı tutulma olarak da adlandırılmaktadır(Kumral, 2017).Örgütsel dışlanma gerçekleştiği sosyal alanlar bağlamı anlamında çalışanların işyerlerinde meydana gelen dışlanmadır. Örgüt 
içerisindeki çalışan ya da grubun işin yapılması esnasında gerekli olan şartlara sahip olan ya da sosyal anlamda kendilerine yakın olanların diğer çalışan ve çalışan grubunu dışarıda bırakmaları için gösterilen eylemler olarak adlandırılmaktadır. Diğer bir deyişle örgütsel dışlanma, bir çalışanın iş arkadaşları tarafından önemsenmemesi, yokmuş gibi davranılması, ihmal edilmesi ve çalışma grubu içindeki eylem ve faaliyetlere katılmasını önemsememe süreci ve faaliyetleridir (Yıldız ve Develi, 2018). Kılıç (2018)'e göre psikoloji, eğitim, sosyoloji, üretim ve hizmetsektörü vb. alanlarda işyerinin günün en fazla geçirildiği alan ve iletişimin zorunlu olduğu önemli sosyal alanlardan olması göz önünde bulundurulduğunda örgütsel dişlanmanın görüldüğ̈̈ ortamlarda psikolojik bozukluğa, elverişsiz iş durumuna, işe devamsızlık durumuna, iş performansına katkı sağlayan unsurların azalmasına neden olduğu ve hem çalışanlara hem de organizasyonlara önemli derecede zarar veren bir etkisi bulunduğu gözlemlenmektedir.

Bireylerin çalıştıkları alanlardan uzaklaştıracak seviyede maddi ve manevi yoksunluk yaşaması, baskı içerisinde hissetmelerine neden olan davranış ve uygulamalar, kişilerarası olumsuz davranışlardan ortaya çıkması ve çalışma ortamındaki iletişim odaklı bağın kopması, geçmiş ilişkilerin olumsuz yönde birikimsel olarak devamlılığı, örgütsel dışlanmayı ele alınmasını gerekli kılmaktadır.

Çalışma ortamında çalışanları dışlamaya yönelik davranışlar, örgüte büyük ölçüde olumsuz tutumlar geliştirmesine neden olabileceği gibi onların işten ayrılma tutumlarına da olumsuz etkileri bulunmaktadır. Genellikle çalışanların çalışma koşullarından tatmin olmaması, işten ayrılma niyetini tetikleyerek çalışanların bağlı bulundukları örgüte sadakat, bağlılık ve performansı gibi öğeleri önemli ölçüde sekteye uğratıp çalışma ortamında olumsuz tutum ve davranışların sergilenmesi gibi durumlara yol açabilmektedir (Soybalı ve Pelit, 2018).Çalışma hayatı, bireylerin sosyal hayatlarının bir parçası olmakla beraber, kariyer, gelecek ve hayat standartlarının belirlenmesinde etkili olan birçok unsurdan biridir. Dolayısıyla, çalıştı̆̆ iş̧eri ya da çalışma hayatında iş arkadaşları tarafından bireyin dışlanması hem örgütsel hem de bireysel düzeyde olumsuz etkiler yaratacaktır. 


\section{Araştırma}

\section{Araştırmanın Amacı}

$\mathrm{Bu}$ noktadan hareketle araştırma geneli çerçevesinde aşağıdaki sorulara cevap aranmiştır.

- Öğretmenlerin; yaşına, cinsiyetine, sosyal ağları kullanım amaçlarına, sosyal ağlarda geçirdiği süreye, çalışma ortamındaki iletişim düzeyi yeterliliğine, meslekte geçirilen çalışma süresine göre örgütsel dışlanma tutumları arasında farklılık var mıdır?

- Öğretmenlerin; yaşına, cinsiyetine, sosyal ağları kullanım amaçlarına, sosyal ağlarda geçirdiği süreye, çalışma ortamındaki iletişim düzeyi yeterliliğine, meslekte geçirilen çalışma süresine göre siber zorbalık tutumları arasında farklılık var midır?

- Eğitim örgütlerinde çalışan öğretmenlerin örgütsel dişlanma tutumları ile siber zorbalık tutumları arasında ilişki var mıdır?

\section{Araștırmanın Önemi}

Örgütsel davranış literatüründe, olumsuz davranışlara yönelik konuların değişen yönetim bakış açısıyla beraber daha fazla önem ve öncelik verildiği görülmektedir. Olumsuz davranışların örgüt ve iş görenlerin verim ve performanslarında yarattığı olumsuz etkinin en aza indirilerek, örgütün farklılaşması ve rekabet üstünlüğü kazanmasında etkili olan nitelikli işgücünün kalmasını ve devamlılığını sağlayıp, bu özgün kaynaktan en üst seviyede yararlanmak görülmektedir (Halis ve Demirel, 2016). Eğitim örgütlerinin önemli ve lokomotif öğelerinden olan öğretmenlerin diğer öğretmenler tarafından önemsenmemesi, ihtiyaç ve ilgilerinin görmezden gelinmesi, yokmuş gibi davranılması öğretmenlerin sosyal, psikolojik ve toplumsal ilişkilerine olumsuz olarak yansıyabilmektedir. Ayrıca bu durumun süreklilik göstermesi mesleğe karşı tutumunun azalması öğrenci-öğretmen, öğretmen-öğretmen ve öğretmenveli ilişkilerinde azalma, olumsuz tutum oluşturma ve okuldaki kararlara yönelik katılımının sınırlandırılması, engellenmesi ve bu kararlara ilgisiz kalması, mesleğe yabancılaşma gibi çok yönlü olumsuz etkileri 
olacağ1 öngörülmüştür (Abasl1, 2018).

\section{Araştırmanın Evreni ve Örneklemi}

Araştırmanın evreni, 2018-2019 Eğitim-Öğretim yılında Edirne il merkezinde Milli Eğitim Bakanlığı'na bağlı okullarda görev yapan öğretmenlerden oluşmaktadır. Araştırmada, Edirne ili evren seçilmiş ve örneklem sayılarını temsil sayısını sağlayacak şekilde tesadüfî çalışma grubu oluşturulmuştur. Çalışmanın evren büyüklügü Edirne merkez için toplam 2000 öğretmenden oluşmaktadır. Bulundukları çevrenin sosyal ve ekonomik yapısı göz önünde bulundurularak Edirne İli üç bölgeye ayrılmış bu bölgeler yüksek-orta-düşük seviyeler olarak belirlenmiş eşit tabakalı örnekleme yöntemi kullanılarak her üç bölgeden eşit sayıda rastgele yolla seçilen bu okullar çalışma grubunu oluşturmuştur. Bu evren büyüklüğünü temsil edecek Edirne merkez ilçelerden gönüllülük esasına riayet edilerek çalışmaya katılan 328 öğretmenden örneklem grubu oluşturulmuş ve katılımcılara Ocak -Mayısayları asında uygulanmıştır. Krejcie ve Morgan (1970)'ın geliştirdikleri örneklem belirleme yöntemi olan; $s=X^{2} N$ P (1- P) / d ${ }^{2}(N-1)+X^{2} P(1-P)$ formülü ile belirlenmiştir. Örneklemin mevcut evreni temsil etme kapasitesi yapılmış hesaplamalarla güven aralığı 0.01 olarak, hata payının ise 0.05 olarak kabul edildiği bu işlem sonucunda \%95 güven aralığı ile \%5 hata payı dikkate alınd1ğında bu araştırmanın evrenini temsil edecek minimum örneklem sayısı 322 olarak hesaplanmıştır.

\section{Araştırmanın Yöntemi, Veri Toplama Araçları ve Ölçekleri}

Eğitim örgütlerinde siber zorbalık davranışları ile örgütsel dışlanma arasındaki ilişkiyi betimleyerek diğer bağımsız değişkenlerin etkilerini de ortaya koymaya yönelik bu araştırma, ilişkisel tarama modelindedir. “Tarama modelleri, geçmişte ya da halen var olan bir durumu varolduğu şekliyle betimlemeyi amaçlayan araştırma yaklaşımlarıdır. Araştırmaya konu olan olay, birey ya da nesne, kendi koşulları içinde ve olduğu gibi tanımlanmaya çalışılır" (Karasar, 2012).

Örgütsel dışlanma tutum algıları bağımsız, siber zorbalığa yönelik tutum algı düzeyleri ise bağımlı değişken olarak ele alınmıştır. 
Araştırmada, 1 adet anket ve alan yazında yer alan iki adet ölçekten faydalanılmıştır. Bu ölçeklerden öğretmenlerin okula, bulundukları çalışma ortamına ve okul yönetime olan tutumlarına, çalıştığı kurumdan uzaklaşma davranışları, performansı düşüren etkenler ile öğretmenlerin uygulamalara katılımına yönelik algılarını tespit eden “Örgütsel Dışlanma Ölçeği" diğeri ise öğretmenlerin siber zorbalığa ilişkin aktif başa çıkma, dışsal kaynaklı başa çıkma ve kaçınmacı başa çıkma davranış ve tutumlarının yeterlilikleri ile bunu ortaya çıkarmaya yönelik görüşlerini ortaya koyan "Siber Zorbalık Ölçeği" dir.

Örgütsel Dışlanma Ölçeği: Sağır ve Oğuz (2012) tarafından yapılan çalışma sonucunda geliştirilen katılımcılara uygulanmış bu ölçek, örgütsel dışlanmaya yönelik davranışlarını belirlemek üzere 25 maddeden oluşmaktadır. Ölçeğin, öz değeri1.00’ın üzerinde dört faktörlü bir yapı sergilediği ve bunların çalıştığ 1 kurumdan (duyuşsal, davranışsal) uzaklaşma, performansı düşüren etkenler, okula karşı olumsuz tutum, çalışanların kararları uygulamalara katılımı başlığ 1 adı altında 4 faktör içerdiği ve bununla birlikte toplam varyansın 0.59 olduğu açıklanmıştır. Ölçeğe faktör analizi yapılmadan veri setinin faktör analizi için uygunluğunun değerlendirilmesi yapılan analizler sonucunda KMO değeri 0.88 olarak ortaya konulmuştur. $\mathrm{KMO}$ değeri $0.88>0.50$ olduğundan faktör analizi için uygun olduğu söylenebilmektedir. Daha sonra Barlett testi sonucunun anlamlı olup olmadığına bakılmış ve veri setinin faktör analizi için uygun olduğu görülmüştür $(\mathrm{p}<.001)$.

Geliştirilmiş ölçekte yer alan maddelerden, faktör yük değeri 0.30 'un altında bulunan on bir madde ölçekten çıkarılmıştır. Ölçeğin tamamı için bulunan Cronbach Alfa Katsayısı 0.89'dur. Tutum ölçerde katılımcıların derecelendirmeleri "Kesinlikle Katılmıyorum, Katılmıyorum, Kararsizım, Katılıyorum, Kesinlikle Katılıyorum" cevaplarıyla yapılmıştır.

Siber Zorbalık Ölçeği: Altundağ ve Ayas (2018) tarafından yapılan çalışma sonucunda geliştirilen katılımcılara uygulanmış olan bu ölçek, siber zorbalığa yönelik davranışlarını ve tutumlarını belirlemek, bilme ve uygulama alanlarına ilişkin yeterliliklerini ortaya koymak üzere 18 madde ve 3 boyuttan oluşmaktadır. Açıklanan toplam varyansın bilme alanında \%41.2, uygulama alanında \%54.03 olduğu bulunmuştur. Birden 
fazla boyutu olan bir ölçme aracında \%40-60 aralığında varyans oranı yeterli kabul edilebilir olduğu görülmüştür. Ölçeğin boyutlarına bakıldığında birinci boyut aktif başa çıkma, ikinci boyut dışsal kaynaklı başa çıkma, üçüncü boyutta kaçınmacı başa çıkma başlığı altında toplanmıştir.

Ölçeğin güvenilirliğine ilişkin Cronbach alfa iç tutarlılık katsayıları incelenmiş olup, bilme alanına ilişkin katsayılar, aktif başa çıkma boyutu için 0.72 , dışsal kaynaklı başa çıkma boyutu için 0.66 ve kaçınmacı başa çıkma boyutu için 0.54 olarak hesaplanmıştır. Uygulama alanındaki ölçümde ise, aktif başa çıkma boyutu için 0.87, dışsal kaynaklı başa çıkma boyutu için 0.78 ve kaçınmacı başa çıkma boyutu 0.66 olarak bulunmuştur. Her iki alana ilişkin iç tutarlılık katsayılarının 0.70 'ten büyük ve yakın değerlere sahip olması, genel olarak iç tutarlılık için yeterli ve kabul edilebilir bir değer olarak görüldüğünden ölçeğin güvenilir ve tutarlı olduğu söylenebilir. Katılımcılara uygulanacak bu ölçek, siber zorbalığa yönelik davranışlarını belirlemek üzere 18 sorudan oluşmaktadır. Tutum ölçerde derecelendirme "Kesinlikle Katılmıyorum, Katılmıyorum, Kararsızım, Katılıyorum, Kesinlikle Katılıyorum" cevaplarıyla yapılacaktır. Ölçeğin geçerlik güvenirlik çalışmaları ölçeği geliştiren araştırmacılar tarafından yapılmıştır.

\section{Verilerin Yorumlanmasıve Araştırmanın Bulguları}

Araştırma yapılacak çalışma grubunun 50'den fazla olmasından Kolmogorov-Smirnov testleri kullanılmış; Tablo 1'de görüldüğü üzere Örgütsel Dışlanma Ölçeği ile Siber Zorbalık Ölçeğinin anlamlılık düzeyinin $(p<0,05)$ küçük çıkması sebebiyle verilerin normal dağılmadığına karar verilmiştir.

Tablo 1. Ölçeklerin Normallik Testi

\begin{tabular}{|c|c|c|c|c|c|c|}
\hline \multirow{2}{*}{$\begin{array}{l}\text { Ölçeklerin Normallik } \\
\text { Testi }\end{array}$} & \multicolumn{3}{|c|}{ Kolmogorov-Smirnova } & \multicolumn{3}{|c|}{ Shapiro-Wilk } \\
\hline & Statistic & $\mathrm{n}$ & $\mathrm{p}$ & Statistic & $\mathrm{n}$ & $\mathrm{p}$ \\
\hline Örgütsel Dışlanma & 061 & 328 & ,005 & ,986 & 328 & ,003 \\
\hline Siber Zorbalık & 136 & 328 & ,000 & 819 & 328 & ,000 \\
\hline
\end{tabular}


Tablo2. Ölçeklerin Betimsel İstatistik Tablosu

\begin{tabular}{llll}
\hline & & İstatistik & Standart Hata \\
\hline & Ortalama & 2,4804 &, 03326 \\
& Medyan & 2,4800 & \\
Örgütsel Dişlanma Ölçeği & Standart Hata &, 363 & \\
& Minimum & 1,00234 & \\
& Maksimum & 4,36 & \\
& Çarpıklık &, 339 &, 135 \\
& Basıklık &,- 100 &, 268 \\
\hline & Ortalama & 4,2259 &, 03887 \\
Siber Zorbalık Ölçeği & Medyan & 4,3333 & \\
& Varyans &, 495 & \\
& Standart Hata &, 70391 & \\
& Minimum & 1,00 & \\
& Maksimum & 5,00 &, 268 \\
\hline
\end{tabular}

Tablo 2'de Örgütsel Dışlanma Ölçeği ve Siber Zorbalık Ölçeğinin çarpıklık ve basıklık değerleri +1 ve -1 aralığında yer almadığından normal dağılım göstermediği görülmektedir.

Buna göre;

1) Öğretmenlerin siber zorbalık tutum ve örgütsel dışlanma tutum algılarından aldıkları puanların; cinsiyet, sosyal ağları kullanım amaçları değişkenlerine göre farklılık gösterip göstermediğini belirlemek için non-parametrik Mann Whitney-U testi,

2) Öğretmenlerin siber zorbalık tutum ve örgütsel dışlanma tutum algılarından aldıkları puanların; yaş, sosyal ağlarda geçirilen süre, çalışma ortamındaki iletişim düzeyi yeterliliği, meslekte geçirilen çalışma süresi değişkenlerine göre farklılık gösterip göstermediğini belirlemek için non-parametrik Kruskal Wallis-H testi,

3) Öğretmenlerin siber zorbalık ve örgütsel dışlanma tutum ölçeğini temsil eden alt boyutlarının cinsiyet, sosyal ağları kullanım amaçları değişkenlerine göre farklılık gösterip göstermediğini belirlemek için non-parametrik Mann Whitney-U testi,

4) Öğretmenlerin siber zorbalık tutum ve örgütsel dişlanma ölçeğini temsil eden alt boyutlarının yaş, sosyal ağlarda geçirilen süre, çalışma ortamındaki iletişim düzeyi yeterliliği, meslekte geçirilen 
çalışma süresi değişkenlerine göre farklılık gösterip göstermediğini belirlemek için non-parametrik Kruskal Wallis-H testi,

5) Öğretmenlerin örgütsel dışlanma ile siber zorbalık tutum algıları ölçeğinin alt boyutları arasındaki ilişkiyi tespit etmek üzere Pearson Çarpım Moment korelasyon analizinden yararlanılmıştır.

6) 6)Bu doğrultuda araştırmanın probleminde belirtilen öğretmenlerin örgütsel dışlanmaya yönelik tutumları ile siber zorbalık tutum düzeyleri arasındaki ilişkiyi tespit etmek amacıyla Spearman's korelasyon katsayısı hesaplanmıştır.

\section{Bulgular}

Öğretmenlerin siber zorbalık tutumları ile örgütsel dışlanma tutumlarının demografik özelliklere göre dağılımı sonucu oluşan ortalama değerleri (x sıra) , kişi sayıları (n) ve anlamlılık değerleri (p) bulguları Tablo 3'de yer almaktadir.

Tablo3. Ölçeklerin Demografik Özelliklere Göre Bulgular

\begin{tabular}{|c|c|c|c|c|c|c|c|}
\hline \multicolumn{2}{|c|}{ Öğretmenlerin Demografik Özellikleri } & \multicolumn{3}{|c|}{$\begin{array}{l}\text { Siber Zorbalık Tutum } \\
\text { Algıları }\end{array}$} & \multicolumn{3}{|c|}{$\begin{array}{l}\text { Örgütsel Dışlanma Tutum } \\
\text { Algıları }\end{array}$} \\
\hline \multirow{4}{*}{ Yaş } & $18-25$ vas & 14 & 149 & \multirow{4}{*}{,14 } & 14 & 146 & \multirow{4}{*}{,06 } \\
\hline & $26-33$ yaş & 67 & 188 & & 67 & 173 & \\
\hline & $34-41$ yaş & 95 & 157 & & 95 & 181 & \\
\hline & 42-üstü & 152 & 159 & & 152 & 151 & \\
\hline \multirow{2}{*}{ Cinsiyet } & Kadın & 185 & 166 & \multirow{2}{*}{,60 } & 185 & 157 & \multirow{2}{*}{,12 } \\
\hline & Erkek & 143 & 161 & & 143 & 173 & \\
\hline \multirow{5}{*}{ 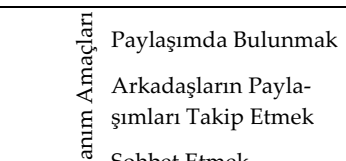 } & Hayır & 227 & 164 & \multirow{2}{*}{96} & 227 & 162 & \multirow{2}{*}{60} \\
\hline & Evet & 101 & 164 & & 101 & 168 & \\
\hline & Hayır & 224 & 166 & \multirow[b]{2}{*}{, 65} & 224 & 168 & \multirow{2}{*}{, 30} \\
\hline & Evet & 104 & 161 & & 104 & 156 & \\
\hline & Hayır & 282 & 164 & \multirow{2}{*}{,91 } & 282 & 164 & \multirow{2}{*}{97} \\
\hline 彗 Sohbet Etmek & Evet & 46 & 163 & & 46 & 164 & \\
\hline \multirow{4}{*}{ 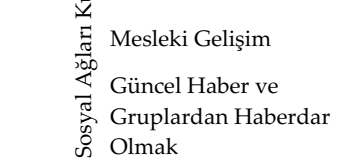 } & Hayır & 234 & 158 & \multirow{2}{*}{, 06} & 234 & 168 & \multirow{2}{*}{,17 } \\
\hline & Evet & 94 & 179 & & 94 & 153 & \\
\hline & Hayır & 125 & 166 & \multirow[b]{2}{*}{, 82} & 125 & 170 & \multirow[b]{2}{*}{40} \\
\hline & Evet & 203 & 163 & & 203 & 161 & \\
\hline \multirow{4}{*}{$\begin{array}{l}\text { Sosyal Ağlarda Günlük Geçirilen } \\
\text { Süre }\end{array}$} & 1 saatten az & 155 & 170 & \multirow{4}{*}{, 40} & 155 & 157 & \multirow{4}{*}{, 31} \\
\hline & 1-3 saat & 159 & 161 & & 159 & 168 & \\
\hline & 4-6 saat & 12 & 128 & & 12 & 206 & \\
\hline & 7- üzeri & 2 & 124 & & 2 & 138 & \\
\hline \multirow{3}{*}{$\begin{array}{l}\text { Çalışma Ortamındaki İletişim } \\
\text { Düzeyi Yeterliliği }\end{array}$} & Evet & 283 & 164 & \multirow{3}{*}{, 55} & 283 & 156 & \multirow{3}{*}{, $00^{*}$} \\
\hline & Hayır & 19 & 182 & & 19 & 235 & \\
\hline & Kararsız & 26 & 151 & & 26 & 205 & \\
\hline
\end{tabular}




\begin{tabular}{llllllll}
\hline & $0-5$ yıl & 42 & 175 & & 42 & 148 & \\
Meslekte Geçirilen Çalışma & $6-10$ yıl & 50 & 183 & \multirow{2}{*}{, 28} & 50 & 187 &, 06 \\
Süresi & $11-15$ yıl & 61 & 162 & & 61 & 180 & \\
& $16-$ üstü & 175 & 156 & & 175 & 155 & \\
\hline
\end{tabular}

Tablo 3'de görüldüğü üzere, öğretmenlerin örgütsel dışlanma tutumlarının çalışma ortamındaki iletişim yeterliliği düzeyi değişkenine göre anlamlı bir farklılık gösterip göstermediğini belirlemek amacıyla yapılan Kruskal Wallis-H testi sonucunda çalışma ortamındaki iletişim yeterliliği düzeyi gruplarının sıralamalar ortalamaları arasındaki fark istatistiksel olarak anlamlı bulunmuştur ( $\mathrm{p}<, 05)$. Bu durumda öğretmenlerin örgütsel dışlanma tutumları ile çalışma ortamındaki iletişim yeterliliği düzeyi arasında anlamlı bir fark bulunduğu görülmektedir. Diğer tüm demografik özelliklerin tüm ölçekler arasında anlamlı bir farklılık göstermediği görülmektedir $(\mathrm{p}>, 05)$.

Tablo4. Siber Zorbalık Ölçeği Boyutlarının Demografik Özelliklere Göre Bulguları

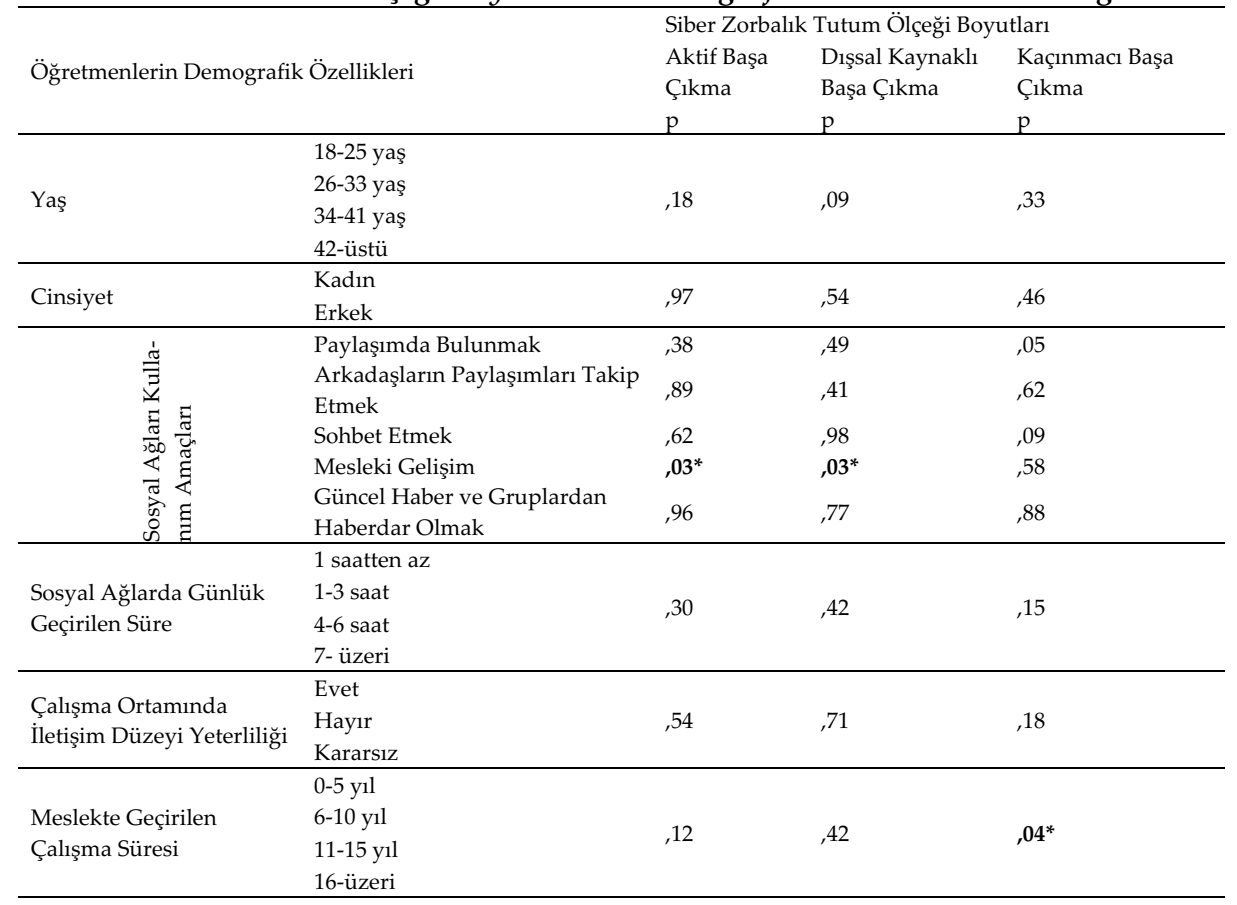


Tablo 4'de siber zorbalık tutum ölçeğinin alt boyutlarının sosyal ağları kullanım amaçları değişkenine göre anlamlı bir farklılık gösterip göstermediğini belirlemek amacıyla yapılan Mann Whitney-U testi sonucunda siber zorbalık boyutlarının sıralamalar ortalamaları arasındaki fark Aktif Başa Çıkma ve Dışsal Kaynaklı Başa Çıkma boyutu için sosyal ağları kullanım amaçları değişkenlerinden Mesleki Gelişim değişkenine göre anlamlı bulunmuş $(p<, 05)$ diğer boyutların tüm değişkenleri için ise anlamlı bulunmamıştır ( $\mathrm{p}>, 05)$. Bu durumda öğretmenlerin siber zorbalık tutumlarının Aktif Başa Çıkma ve Dışsal Kaynaklı Başa Çıkma boyutlarının mesleki gelişim değişkenine göre anlamlı bir fark gösterdiği görülmektedir.

Ayrıca ölçeğinin alt boyutlarının meslekte geçirilen çalışma süresi değişkenine göre anlamlı bir farklılık gösterip göstermediğini belirlemek amacıyla yapılan Kruskal Wallis-H testi sonucunda ölçeğin boyutlarının sıralamalar ortalamaları arasındaki fark meslekte geçirilen çalışma süresi değişkenine göre Kaçınmacı Başa Çıkma Boyutu istatistiksel olarak anlamlı bulunmuş $(p<, 05)$ diğer boyutlar için ise anlamlı bulunmamıştır $(\mathrm{p}>, 05)$. Bu durumda öğretmenlerin siber zorbalık tutumlarının alt boyutlarının meslekte geçirilen çalışma süresi değişkenine göre Kaçınmacı Başa Çıkma boyutunun anlamlı fark gösterdiği görülmektedir. Diğer tüm demografik özelliklerindeğişkenleri siber zorbalık ölçeğinin alt boyutlarına göre anlamlı bir farklılık göstermediği görülmektedir.

Tablo 5'de görüldüğü üzere, örgütsel dişlanma tutum ölçeğinin alt boyutlarının cinsiyet değişkenine göre anlamlı bir farklılık gösterip göstermediğini belirlemek amaciyla yapılan Mann Whitney-U testi sonucunda örgütsel dışlanma boyutları gruplarının sıralamalar ortalamaları arasındaki fark Çalıştığı Kurumdan Uzaklaşma ve Çalışanların Kararları Uygulamalara Katılımı boyutu için cinsiyet değişkenine göre anlamlı bulunmuş $(p<, 05)$ diğer boyutlar için ise anlamlı bulunmamıştır $(p>, 05)$. $\mathrm{Bu}$ durumda öğretmenlerin örgütsel dışlanma tutumlarının Çalıştığ 1 Kurumdan Uzaklaşma ve Çalışanların Kararları Uygulamalara Katılımı boyutunun cinsiyet değişkenine göre anlamlı bir fark gösterdiği görülmektedir.

Örgütsel dışlanma tutum ölçeğinin alt boyutlarının sosyal ağları kullanım amaçları değişkenine göre anlamlı bir farklılık gösterip göstermediğini belirlemek amaciyla yapılan Mann Whitney-U testi sonucunda 
örgütsel dışlanma boyutlarının sıralamalar ortalamaları arasındaki fark Çalıştığı Kurumdan Uzaklaşma, Okula Karşı Olumsuz Tutum ve Çalışanların Kararları ve Uygulamalara Katılımı boyutu için sosyal ağları kullanım amaçları değişkenlerinden Mesleki Gelişim değişkenine göre anlamlı bulunmuş $(p<, 05)$ diğer boyutların tüm değişkenleri için ise anlamlı bulunmamıştır ( $\mathrm{p}>, 05)$.

Tablo5. Örgütsel Dışlanma Ölçeği Boyutlarnın Demografik Özelliklere Göre Bulgularn

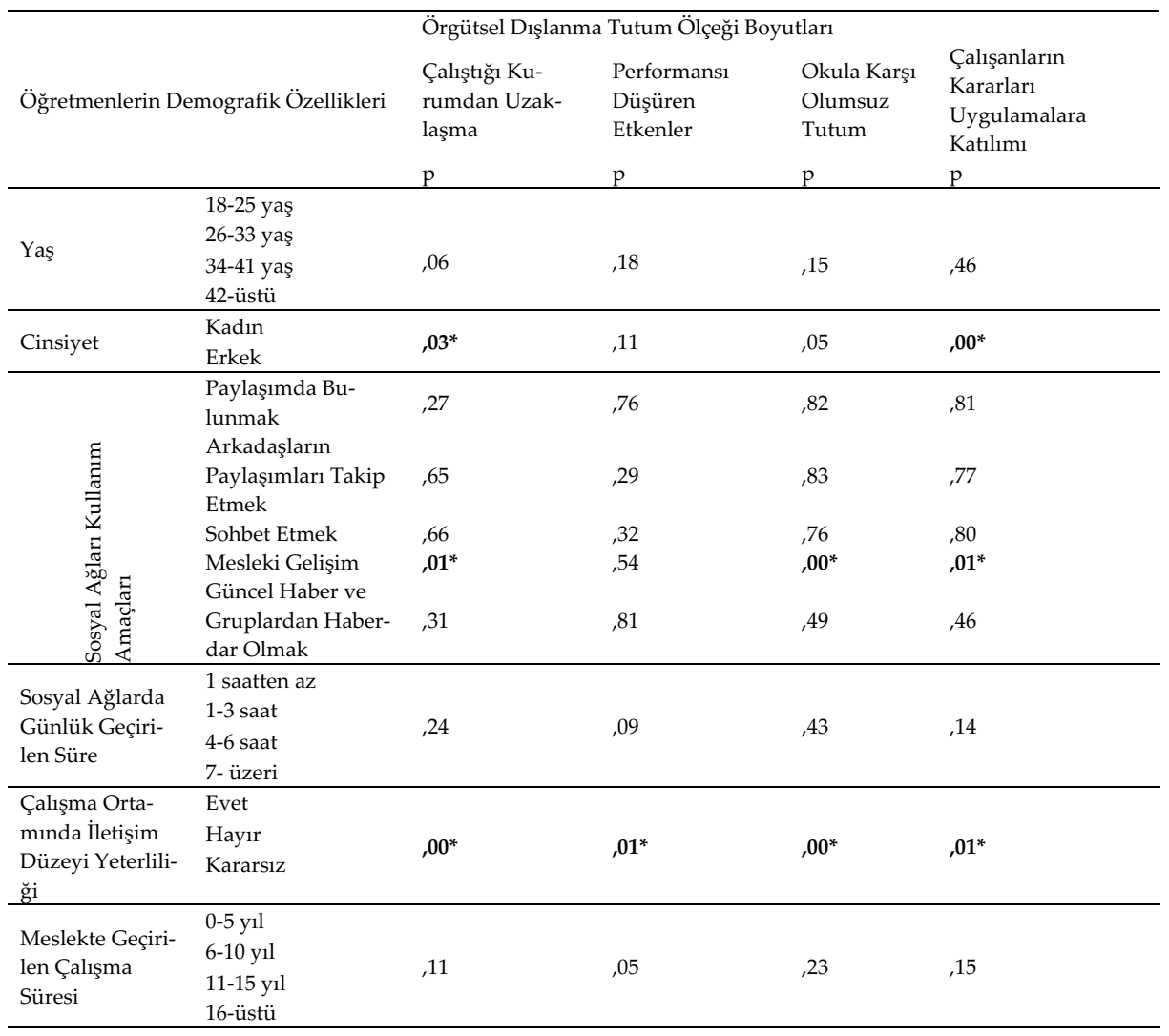

Bu durumda öğretmenlerin örgütsel dışlanma tutumlarının Çalıştığ KurumdanUzaklaşma, Okula Karşı Olumsuz Tutum ve Çalışanların Kararları ve Uygulamalara Katılımı boyutlarının mesleki gelişim değişkenine göre anlamlı bir fark gösterdiği görülmektedir.

Ör- 
gütsel dişlanma tutum ölçeğinin alt boyutlarının çalışma ortamındaki iletişim yeterliliği düzeyi değişkenine göre anlamlı bir farklılık gösterip göstermediğini belirlemek amacıyla yapılan Kruskal Wallis-H testi sonucunda örgütsel dışlanma ölçeği boyutlarının sıralamalar ortalamaları arasındaki fark çalışma ortamındaki iletişim yeterliliği düzeyi değişkeni için istatistiksel olarak anlamlı bulunmuştur $(p<, 05)$. Bu durumda öğretmenlerin örgütsel dışlanma tutumlarının tüm alt boyutlarının çalışma ortamındaki iletişim yeterliliği düzeyi değişkenine göre anlamlı bir fark gösterdiği görülmektedir. Diğer tüm demografik özelliklerin değişkenleri örgütsel dışlanma ölçeğinin alt boyutlarına göre anlamlı bir farklılık göstermediği görülmektedir.

Tablo6. Örgütsel Dışlanma İle Siber Zorbalık Tutum Ölçeği Boyutlarının Arasındaki İlişki

\begin{tabular}{|c|c|c|c|c|}
\hline $\begin{array}{l}\text { Örgütsel Dışlanma } \\
\text { Ölçeği Boyutları }\end{array}$ & Siber Zorbalık Ölçeği Boyutları & $r$ & $p$ & $n$ \\
\hline \multirow{3}{*}{$\begin{array}{l}\text { Çalıştığı Kurumdan } \\
\text { Uzaklaşma }\end{array}$} & Aktif Başa Çıkma &,- 060 & 281 & 328 \\
\hline & Dışsal Kaynaklı Başa Çıkma &,- 033 &, 556 & 328 \\
\hline & Kaçınmacı Başa Çıkma &,- 076 & 171 & 328 \\
\hline \multirow{3}{*}{$\begin{array}{l}\text { Performansı } \\
\text { Düşüren Etkenler }\end{array}$} & Aktif Başa Çıkma &,- 017 & 761 & 328 \\
\hline & Dışsal Kaynaklı Başa Çıkma &,- 035 & ,533 & 328 \\
\hline & Kaçınmacı Başa Çıkma &,- 034 &, 540 & 328 \\
\hline \multirow{3}{*}{$\begin{array}{l}\text { Okula Karşı Olum- } \\
\text { suz Tutum }\end{array}$} & Aktif Başa Çıkma &,- 183 &, $001^{*}$ & 328 \\
\hline & Dışsal Kaynaklı Başa Çıkma &,- 122 &, $027^{*}$ & 328 \\
\hline & Kaçınmacı Başa Çıkma &,- 108 &, 051 & 328 \\
\hline \multirow{3}{*}{$\begin{array}{l}\text { Çalışanların Karar- } \\
\text { ları Uygulamalara } \\
\text { Katılımı }\end{array}$} & Aktif Başa Çıkma & ,438 & , $000^{*}$ & 328 \\
\hline & Dışsal Kaynaklı Başa Çıkma & 358 &, $000^{*}$ & 328 \\
\hline & Kaçınmacı Başa Çıkma & 223 &, $000^{*}$ & 328 \\
\hline
\end{tabular}

Tablo 6'da örgütsel dışlanma tutum ölçeğinin alt boyutları ile siber zorbalık tutum ölçeğinin alt boyutları arasındaki ilişkiyi ortaya koymak üzere Pearson Çarpım Moment Korelasyon analizi sonucunda örgütsel dışlanma tutum ölçeğinin alt boyutlarından Okula Karşı Olumsuz Tutum Boyutu ile siber zorbalık ölçeğinin Aktif Başa Çıkma ve Dışsal Kaynaklı Başa Çıkma boyutları arasında negatif yönlü anlamlı bir ilişki olduğu görülmektedir. Ayrıca örgütsel dışlanma ölçeğinin alt boyutlarından Çalışanların Kararları Uygulamalara Katılımı boyutu ile siber zorbalık tutum ölçeğinin tüm boyutları arasında pozitif yönlü anlamlı bir ilişki olduğu görülmektedir. 
Tablo 7.Öğretmenlerin Örgütsel Dışlanma Tutumlarn ile Siber Zorbalık Tutumlan Arasındaki İlişkiyi Belirlemek Üzere Yapılan Spearman's Korelasyon Analizi Sonuçlari

\begin{tabular}{lcll}
\hline $\begin{array}{l}\text { Siber Zorbalık İle Örgütsel Dış- } \\
\text { lanma Arasındaki İlişki }\end{array}$ & Örgütsel Dışlanma Ölçeği & Siber Zorbalık Ölçeği \\
\hline Örgütsel Dışlanma & $\mathrm{r}$ & 1,000 & $\mathbf{- 1 , 2 \mathbf { 9 } ^ { * }}$ \\
Ölçeği & $\mathrm{p}$ & &, 020 \\
& $\mathrm{n}$ & 328 & 328 \\
Siber Zorbalık & $\mathrm{r}$ & $\mathbf{- 1 , 2 9 ^ { * }}$ & 1,000 \\
Ölçeği & $\mathrm{p}$ & $\mathbf{1 0 2 0}$ & \\
& $\mathrm{n}$ & 328 & 328 \\
\hline
\end{tabular}

Tablo 7'de görüldüğü gibi, çalışma grubuna uygulanmış öğretmenler tarafından yanıtlanan örgütsel dışlanma tutum ölçeğinden alınan puanların ortalaması ile siber zorbalık tutum ölçeği puanlarının ortalaması arasındaki ilişkiyi belirlemek üzere yapılan Spearman'skolerasyon sonucunda puanlar arasında istatistiksel açıdan $p<0,05$ anlamlılık düzeyine göre negatif yönde çok düşük düzeyde anlamlı bir ilişki bulunmuştur (r= $-1,29 ; \mathrm{p}<0,05)$.

\section{Sonuç ve Öneriler}

Edirne ilindeki eğitim örgütlerinde görev yapan öğretmenlerin siber zorbalık tutumları ile örgütsel dışlanma tutumları arasındaki ilişkiyi ortaya koymak amacıyla yapılan bu çalışma da öğretmenlerin örgütsel dışlanma tutumları ölçeği sıralamalar ortalamalarının yaşları değişkenine göre yaş grupları sıralamalar ortalamalarının arasındaki fark istatistiksel olarak anlamlı bulunmamıştır.

$\mathrm{Bu}$ durumda öğretmenlerin örgütsel dışlanma tutumları ile yaşları arasında anlamlı bir fark bulunmadığı görülmektedir. (Dönmez ve Mete, 2019) yaptığı çalışmada da benzer bulgu tespit edilmiştir. Öğretmenlerin siber zorbalık tutumları ölçeği sıralamalar ortalamalarının yaşları değişkenine göre yaş grupları sıralamalar ortalamaları arasındaki fark istatistiksel olarak anlamlı bulunmamıştır. Bu durumda öğretmenlerin siber zorbalık tutumları ile yaşları arasında anlamlı bir fark bulunmadığı görülmektedir. Öğretmenlerin örgütsel dışlanma tutumları ölçeği sıralamalar ortalamalarının cinsiyetleri değişkenine göre cinsiyet grupları sıra- 
lamalar ortalamalarının arasındaki fark istatistiksel olarak anlamlı bulunmamıştır. Kumral (2017) tarafından yapılmış çalışmada katılımcıların örgütsel dışlanmaya yönelik görüşlerinin cinsiyet değişkeni açısından istatistiksel olarak farklılaşmadığı saptanmıştır. Bu durumda öğretmenlerin örgütsel dışlanma tutumları ile cinsiyetleri arasında anlamlı bir fark bulunmadığ1 görülmektedir. Koşar (2014) tarafından yapılmış çalışma bulgularında ise Mersin Üniversitesinde görev yapan akademik ve idari personelin işyerinde dışlanmaya ilişkin görüşlerinin cinsiyete göre anlamlı bir farklılık gösterdiği görülmüştür.

Öğretmenlerin siber zorbalık tutumları ölçeği sıralamalar ortalamalarının cinsiyet değişkenine göre cinsiyet grupları sıralamalar ortalamaları arasındaki fark istatistiksel olarak anlamlı bulunmamıştır. Bu durumda öğretmenlerin siber zorbalık tutumları ile cinsiyetleri arasında anlamlı bir fark bulunmadığı görülmektedir. Öğretmenlerin örgütsel dışlanma tutumları ölçeği sıralamalar ortalamalarının sosyal ağ kullanım amaçları değişkenine göre sosyal ağları kullanım amaçları gruplarının sıralamalar ortalamaları arasındaki fark tüm yanıtlar için istatistiksel olarak anlamlı bulunmamıştır. Bu durumda öğretmenlerin örgütsel dışlanma tutumları ile sosyal ağları kullanım amaçları arasında anlamlı bir fark bulunmadığı görülmektedir. Öğretmenlerin siber zorbalık tutumları ölçeği sıralamalar ortalamalarının sosyal ă̆ kullanım amaçları değişkenine göre sosyal ağları kullanım amaçları gruplarının sıralamalar ortalamaları arasındaki fark tüm yanıtlar için istatistiksel olarak anlamlı bulunmamıştır. Bu durumda öğretmenlerin siber zorbalık tutumları ile sosyal ağları kullanım amaçları arasında anlamlı bir fark bulunmadı̆̆ı görülmektedir.Öğretmenlerin örgütsel dışlanma tutumları ölçeği sıralamalar ortalamalarının sosyal ağlarda geçirdiği süre değişkenlerinin sıralamaları ortalamalarına göre arasındaki fark istatistiksel olarak anlamlı bulunmamıştır. Bu durumda öğretmenlerin örgütsel dışlanma tutumları ile sosyal ağlarda geçirilen süre arasında anlamlı bir fark bulunmadığ1 görülmektedir. Öğretmenlerin siber zorbalık tutumları ölçeği sıralamalar ortalamalarının sosyal ağlarda geçirilen sürenin gruplarının sıralamalar ortalamaları arasındaki fark istatistiksel olarak anlamlı bulunmamıştır. $\mathrm{Bu}$ durumda öğretmenlerin siber zorbalık tutumları ile sosyal ağlarda geçirilen süre arasında anlamlı bir fark bulunmadığı görülmektedir. Öğretmenlerin örgütsel dışlanma tutumları ölçeği sıralamalar ortalamaları- 
nın çalışma ortamındaki iletişim yeterliliği düzeyi değişkenine göre sıralamalar ortalamaları arasındaki fark istatistiksel olarak anlamlı bulunmuştur. Bu durumda öğretmenlerin örgütsel dışlanma tutumları ile çalışma ortamındaki iletişim yeterliliği düzeyi arasında anlamlı bir fark bulunduğu görülmektedir.

Öğretmenlerin siber zorbalık tutumları ölçeği sıralamalar ortalamalarının çalışma ortamındaki iletişim yeterliliği düzeyi değişkenine göre sıralamalar ortalamaları arasındaki fark istatistiksel olarak anlamlı bulunmamıştır. Bu durumda öğretmenlerin siber zorbalık tutumları ile çalışma ortamındaki iletişim yeterliliği düzeyi arasında anlamlı bir fark bulunmadığı görülmektedir.

Öğretmenlerin örgütsel dışlanma tutumları ölçeği sıralamalar ortalamalarının meslekte geçirilen çalışma süresi değişkenine göre sıralamalar ortalamaları arasındaki fark istatistiksel olarak anlamlı bulunmamıştır. $\mathrm{Bu}$ durumda öğretmenlerin örgütsel dışlanma tutumları ile meslekte geçirilen çalışma süresi arasında anlamlı bir fark bulunmadığı görülmektedir. Öğretmenlerin siber zorbalık tutumları ölçeği sıralamalar ortalamalarının meslekte geçirilen çalışma süresi değişkenine göre sıralamalar ortalamaları arasındaki fark istatistiksel olarak anlamlı bulunmamıştır. $\mathrm{Bu}$ durumda öğretmenlerin siber zorbalık tutumları ile meslekte geçirilen çalışma süresi arasında anlamlı bir fark bulunmadığı görülmektedir.

Araştırmanın çalışma grubunu oluşturan öğretmenler tarafından yanıtlanan örgütsel dışlanma tutum ölçeğinden alınan puanların ortalaması ile siber zorbalık tutum ölçeği puanlarının ortalaması arasındaki negatif yönde çok düşük düzeyde anlamlı bir ilişki bulunmuştur. Örgütsel dışlanma tutum ölçeğinin alt boyutları ile siber zorbalık tutum ölçeğinin alt boyutları arasında örgütsel dışlanma tutum ölçeğinin alt boyutlarından Okula Karşı Olumsuz Tutum Boyutu ile siber zorbalık ölçeğinin Aktif Başa Çıkma ve Dışsal Kaynaklı Başa Çıkma boyutları arasında negatif yönlü anlamlı bir ilişki olduğu görülmektedir. Ayrıca örgütsel dışlanma ölçeğinin alt boyutlarından Çalışanların Kararları Uygulamalara Katılımı boyutu ile siber zorbalık tutum ölçeğinin Aktif Başa Çıkma, Dışsal Kaynaklı Başa Çıkma ve Kaçınmacı Başa Çıkma boyutları arasında pozitif yönlü anlamlı bir ilişki olduğu görülmektedir.

Buna göre; 
- Eğitim örgütlerinde iletişimi ve grup etkinliklerini, organizasyonu destekleyici faaliyetler arttırılabilir.

- Siber zorbalığın eğitim örgütlerinin iklimi ve üzerindeki olumsuz etkileri ile ilgili farkındalık ve çözüm önerilerine yönelik bilgilendirilmeler yapılabilir, toplantılar düzenlenebilir.

- Eğitim örgütlerinde örgütsel dişlanmanın ciddiyetini değerlendirmek için önleyici bilgilendirme programları hazırlayabilir ve olumsuz sonuçları hakkında bilgilendirilmeler ve faaliyetler yapılabilir.

- Öğretmenlerimizin motivasyonunu ve çalışma ortamı içerisindeki iletişimini destekleyici faaliyetler yapılabilir.

- Öğretmenlerimize siber zorbalıkla ilgili farkındalık eğitimleri ile çalışma ortamı içerisindeki iletişimini engelleyici, kısıtlayıcı ve bunun olumsuz sonuçlarından koruyucu ve önleyici hizmet içi eğitimler yapılabilir. 
EXTENDED ABSTRACT

\section{The Relationship between Cyberbullying and Organizational Exclusion in Educational Organizations \\ TuğrulÖz - Yar Ali Mete \\ Trakya University}

Cyberbullying is a form of aggression that consists of technically and relationally damaging actions that can threaten social, psychological and social relations and are continuing, and technically and relationally damaging through information technologies (Korkmaz, 2016). With the proliferation of information technologies and their existence in all aspects, it has been observed that it can be made more easily by moving to the virtual environment in unwanted harmful behaviors and it has been observed that these behaviors have become widespread (Peker, 2015). In cyberbullying, which is similar to the behavior and actions in traditional bullying, the victim is called a victim, and the victim is a cyberbully. It is often referred to as repetitive actions in order to harm the purposeful and deliberate opposing individual or group (Tamer and Vatanarleyen, 2015).While traditional bullying is a known form of harassment encountered in daily life, cyber bullying has the opportunity to be realized in a virtual environment independent of location and time (Peker, Eroğlu and Ada, 2012).

The frequency and prevalence of cyberbullying have been handled by many researchers. In studies conducted in which form and environments cyberbullying took place, it was observed that it was mostly encountered among youth and online environments. In a study carried out in the United States in 2007, it was revealed that cyberbullying behavior and actions mostly occur through messaging, e-mail and chat rooms. However, by expanding this scope in 2009, computers, mobile phones, etc. that we use frequently today. has been expanded to include such devices (Sayımer\&Akca, 2017).If exclusion is; Ignoring or ignoring people from their environment is defined as all actions involving their behavior. It is also a source of interpersonal stress that can lead to psychological problems in individuals. Exclusion, in other words, is a lack of attention and 
direct communication against a person or group (Çelik and Koşar, 2015). Organizational exclusion is also called disregard or exclusion outside the group by more than one person (Kumral, 2017).

Organizational exclusion is the exclusion occurring in the workplaces of the employees in terms of the context of social areas where it occurs. It is called the actions taken for the employee or group within the organization who have the necessary conditions during the work or who are socially close to them to exclude the other group of employees and employees. In other words, organizational exclusion is the process and activities of ignoring an employee by his colleagues, treating them as if they were absent, neglecting them, and ignoring their participation in actions and activities within the working group (Ylld1z and Develi, 2018). According to K1lıç (2018), psychology, education, sociology, production and service sector etc. Considering the fact that the workplace is one of the areas where the day is spent the most and the important social areas where communication is compulsory, there is a significant damage to both employees and organizations that cause organizational exclusion, the factors that contribute to psychological disorder, unfavorable work situation, absenteeism, and job performance. It is observed that it has a giving effect.The purpose of this research; To reveal the relationship between the cyber bullying attitudes and organizational exclusion attitudes of teachers working in educational organizations in Edirne province.

The study group of the research consisted of 328 teachers working in public / private primary and secondary schools in Edirne in the 2017-2018 academic year. As a data collection tool, 3-Dimensional Cyberbullying Scale and 4-Dimensional Organizational Exclusion Scale were applied to teachers on a voluntary basis, with the permission of researchers. In this study to reveal the relationship between cyberbullying behaviors and organizational exclusion and the effects of other independent variables, the relational screening model and the general screening model were used together. According to the findings obtained, it was revealed that there was a low level of negative relationship in the Spearman's analysis of the mean of the cyberbullying scale that the teachers answered and the average of the organizational exclusion scale.As a result of the collation analysis conducted to reveal the relationship between the sub-dimensions of the organizational exclusion attitude scale and the sub-dimensions of the 
cyberbullying attitude scale, the negative dimensions between the Negative Attitude Against School and the Active Coping and Externally Coping dimensions of the cyberbullying scale it seems that there is a relationship. In addition, it is observed that there is a positive positive relationship between the sub-dimensions of the organizational exclusion scale, Participation of Employees in Decisions, and the cyberbullying attitude scale, Active Coping, External Coping and Avoiding Coping dimensions.In the findings related to the independent variables, it was seen that organizational exclusion attitudes differed only by the communication level adequacy variable in the working environment.

\section{Kaynakça/ References}

Abaslı, K. (2018). Örgütsel dışlanma,işe yabancılaşma ve örgütsel sinizm ilişkisine yönelik öğretmen görüşleri. Doktora Tezi. Eğitim Bilimleri Enstitüsü, Hacettepe Üniversitesi, Ankara.

Akca, E., Sayımer, İ., Salı, J., ve Başak, B. (2014). Okulda Siber zorbalığın nedenleri,türleri ve medya okuryazarlığı eğitiminin önleyici çalışmalardaki yeri. Elektronik Mesleki Gelişim ve Araştırma Dergisi (EJOIR), 2(Özel Sayı), 17-28.

Altundağ, Y., ve Ayas, T. (2018). Öğretmenler için sanal zorbalıkla başa çıkma stratejileri ölçeği: Geçerlilik ve güvenilirlik çalışması. Anadolu Psikiyatri Dergisi, 19(1), 84-92.

Baştak, G., ve Altınova, H. (2015). Lise öğrencilerinde yaratıcı drama yöntemiyle siber zorbalık hakkında duyarlılık oluşturma. Yaratıcı Drama Dergisi, 10(1), 93.

Batmaz, M., ve Ayas, T. (2013). İlköğretim ikinci kademedeki öğrencilerin psikolojik belirtilere göre sanal zorbalık düzeylerinin yordanması. Sakarya University Journal of Education, 3(1), 43-53.

Coyne, I., Farley, S., Axtell, C., Sprigg, C., Best, L. and Kwok, O. (2017). Understanding the relationship between experiencing workplace cyberbullying, employee mental strain and job satisfaction: A dysempowerment approach. The International Journal of Human Resource Management 28(7), 945-972.

Çakmakçı, N. (2018). Hürriyet. Eylül 13, 2018 tarihinde http://www.hurriyet.com.tr/egitim/ogretmenlerin-yarisi-siberzorbalik-magduru-40700216 adresinden alındı 
Çelik, C., ve Koşar, A. (2015). Örgüt kültürü ve işyerinde dışlanma arasındaki ilişki Mersin Üniversitesi çalışanları üzerinde bir uygulama. Çukurova Üniversitesi Sosyal Bilimler Enstitüsü Dergisi, 24(2), 47-62.

Dalmaç Polat, Z., ve Bayraktar, S. (2016). Ergenlerde siber zorbalık ve siber mağduriyet ile ilişkili değişkenlerin incelenmesi. Mediterranean Journal of Humanities, 6(1), 116.

Doğan, B., ve Altunoğlu, E. (2014). Bilgi yönetimi, örgüt kültürü, örgüt yapıSı ve performans ilişkileri: Sivil toplum kuruluşları üzerine bir inceleme. Ömer Halisdemir Üniversitesi İktisadi ve İdari Bilimler Fakültesi Dergisi, 7(3), 45.

Dönmez, H. (2018). Tekirdağ'da görev yapan öğretmenleri örgütsel dişlanma düzeyi. Yüksek Lisans Tezi, Sosyal Bilimler Enstitüsü, Trakya Üniversitesi, Edirne.

Dönmez,H.ve Mete,Y.( 2019). Tekirdağ'da görev yapan öğretmenlerin örgütsel dışlanma düzeyleri.Trakya Üniversitesi Eğitim Fakültesi Dergisi, 9(2), 350-365

Erdemli, Ö., ve Kurum, G. (2021). Okul yöneticisi ve öğretmenlerin gözünden okulda dışlanma:Nedenleri ve sonuçları. Hacettepe Üniversitesi Ĕ̆itim Fakültesi Dergisi,36(2), 350-368.

Erdur-Baker, Ö., ve Kavşut, F. (2007). Akran zorbalığının yeni yüzü: Siber zorbalık . Eurasian Journal of Educational Research,27, 31-42.

Güzel, M. (2006). Küreselleşme, internet ve gençlik kültürü. Küresel İletişim Dergisi,1, 14.

Halis, M., ve Demirel, Y. (2016). Sosyal desteğin örgütsel soyutlanma (Dışlanma) üzerine etkisi. Kastamonu Üniversitesi İktisadi ve İdari Bilimler Dergisi, 11, 331-332.

İşginöz, R., ve Bülbül, T. (2012). Okulda diyalog: Okul yönetiminin rolü. Eğitim Bilimleri Araştırmaları Dergisi, 2(1), 127.

Kanbur, A., ve Kanbur, E. (2018). İşyerinde Siber Zorbalık Ölçeği'nin Türkçeye uyarlanması: Geçerlik ve güvenirlik sınama çalışması. Psikoloji Çalışmaları, 38(2), 237-258.

Karakulakoğlu, S. E. (2012). Sosyal medyanın karanlık yüzü. The Turkish Online Journal of Design, Art and Communication, 2(4), 33.

Kılıç, B. (2018). İşyerinde yalnızlık ve işyerinde dışlanma sarmalında presenteeism:Bankacllık sektöründe bir araştırma. Yüksek Lisans Tezi.Sosyal Bilimler Enstitüsü, İşletme, Selçuk Üniversitesi, Konya. 
Kumral, T. (2017). İşyeri nezaketsizliği ve örgütsel sessizlik ilişkisinde örgütsel dışlanmanın aracı rolü. (Yayınlanmamış yüksek lisans tezi), Marmara Üniversitesi Sosyal Bilimler Enstitüsü, İstanbul

Koşar, A. (2014). Örgüt kültürü ve işyerinde dışlanma arasındaki ilişkinin mersin üniversitesi' nde çalışanlar üzerinde incelenmesi. Yüksek Lisans Tezi. Mersin Üniversitesi, Sosyal Bilimler Enstitüsü, Mersin.

Korkmaz, A. (2016). Siber zorbalık davranışları sergileme ve siber zorbalığa maruz kalma durumlarının karşılaştırılması. Trt Akademi Dergisi, $1(2), 623-624$.

Krejcie, R. and Morgan, D. (1970). Determining sample size for research activities.Educational And Psychological Measurement,30, 607-610.

Kumral, T. (2017). İşyeri nezaketsizliği ve örgütsel sessizlik ilişkisinde örgütsel dışlanmanın aracı rolü. Yüksek Lisans Tezi.Eğitim Bilimleri Enstitüsü, Eğitim Bilimler, Marmara Üniversitesi, İstanbul.

Milliyet. (2012, Ocak 16). Milliyet. Ocak 16, 2019 tarihinde Milliyet: http://www.milliyet.com.tr/sanal-zorbalik-olum-getirdi/dunya/haberdetay/16.01.2012/1489583/default.htm adresinden alınd1

Peker, A. (2015). Ortaokul öğrencilerinin siber zorbalık statülerini yordayan risk faktörlerinin incelenmesi. Eğitim ve Bilim Dergisi, 40(141), 58.

Peker, A., ve İskender, M. (2015). İnsani değerler yönelimli psiko-eğitim programının siber zorbalık üzerindeki etkisi. Atatürk Üniversitesi Sosyal Bilimler Enstitüsü Dergisi, 19(1), 11-22.

Peker, A., Eroğlu, Y. ve Ada, Ş. (2012). Ergenlerde siber zorbalığın ve mağduriyetin yordayıc1larının incelenmesi. Abant İzzet Baysal Üniversitesi Eğitim Fakültesi Dergisi, 12(2), 188.

Sağır, T. ve Oğuz, E. (2012). Öğretmenlere yönelik örgütsel sinizm ölçeğinin geliştirilmesi. International Journal of Human Sciences, 9(2), 1094-1106.

Sayımer, İ. ve Akca, E. (2017). Siber zorbalık kavramı, türleri ve ilişkili olduğu faktörler: Mevcut araştırmalar üzerinden bir değerlendirme. AJIT-e: Online Academic Journal of Information Technology, 8(30), 5-9.

Serin, H. (2012). Ergenlerde siber zorbalı / siber mağduriyet yaşantıları ve bu davranışlara ilişkin öğretmen ve eğitim yöneticilerinin görüşleri.Doktora Tezi.Sosyal Bilimler Enstitüsü, Eğitim Bilimleri, İstanbul Üniversitesi, İstanbul. 
Soybalı, H., ve Pelit, O. (2018). Örgütsel dışlanmanın işten ayrılma niyetine etkisi:Afyonkarahisar'daki beş yıldızlı otel işletmelerinde bir araştırma. Afyon Kocatepe Üniversitesi Sosyal Bilimler Dergisi, 20(3), 225249.

Şahin, M., Sarı, S., Özer, Ö. ve Er, S. (2010). Lise öğrencilerinin siber zorba davranışlarda bulunma ve maruz kalma durumlarına ilişkin görüşleri. Süleyman Demirel Üniversitesi Fen Edebiyat Fakültesi Sosyal Bilimler Dergisi , 21, 258-268.

Tamer, N. ve Vatanartıran, S. (2015). Ergenlerin teknolojik zorbalık farkındalığ1 eğitimine yönelik bir pilot uygulama. Milli Ĕ̆itim Dergisi, 45(207), 40-41.

Tuik. (2018). Türkiye İstatistik Кurumu. Nisan Sall, 2019 tarihinde http://www.tuik.gov.tr/PreHaberBultenleri.do?id=27819 adresinden alınd 1

Uluçay, D. ve Melek, G. (2017). Türkiye'deki okullarda siber zorbalık: Bir literatür değerlendirmesi. AJIT-e: Online Academic Journal of Information Technology, 8(30), 92-102.

Ümmetler İlhan, A. (2016). Ortä̈ğretim öğrencilerinin siber zorbalı ve internet saldırganlık düzeyleri ile sosyal medyaya ilişkin tutumlarının incelenmesi (Çekmeköy örneği). Yüksek Lisans Tezi.Sosyal Bilimler Enstitüsü, Eğitim Bilimleri, Yeditepe Üniversitesi, İstanbul.

Yıldız, H., ve Develi, A. (2018). Çalışanların yalan söyleme eğiliminin bir öncülü olarak örgütsel dışlanma. Anemon Muş Alparslan Üniversitesi Sosyal Bilimler Dergisi, 6(18), 142.

\section{Kaynakça Bilgisi / Citation Information}

Öz, T. ve Mete, Y. A.(2021). Eğitim örgütlerinde siber zorbalık tutumları ile örgütsel dışlanma arasındaki ilişki. OPUS-Uluslararası Toplum Araştırmaları Dergisi, 18(Yönetim ve Organizasyon Özel Sayısı), 1194-1222. DOI: 10.26466/opus.894335. 